\title{
カトリック手取教会の営繕と災 害復旧
}

\section{MAINTENANCE AND POST-DISASTER RESTORATION OF CATHOLIC TETORI $\mathrm{CHURCH}$}

\section{福島綾子—— $* 1$}

キーワード

教会, カトリック, 災害, 復旧, 営繯

Keywords:

Church, Catholic, Disaster, Restoration, Maintenance

\section{Ayako FUKUSHIMA - $* 1$}

This study aims to understand how and why a historic building of Catholic Tetori Church was restored promptly after Kumamoto Earthquakes in 2016. The study revealed the lay members of the Church were the main force: they, some of whom were building professionals, had established the building maintenance system since 2006 and carried out preventive maintenance. Such a proactive attitude was nurtured by the progressive Columban missionaries. The laity also find voluntary maintenance activities a joy to serve God and fellow Catholics, hence, devote more time after their retirement. These factors prevented serious damages by earthquakes and enabled prompt restoration.

\section{1. 被災宗教建築の自立的復旧}

2016 年 4 月に発生した熊本地震では多くの歴史的宗教建築も被 災した ${ }^{1)}$ 。国指定重要文化財の宗教建築は公費による復旧が担保さ れているが、国や地方自治体による文化財指定がなければ、原則的 には修復の公的支援を受けられない。大規模災害時には未指定宗教 建築復旧のための指定寄付金制度など特例の公的支援が措置される ことがあるが、措置がとられるまでの時間がかかり、また、措置後 も公的支援の周知がなかなか行き届かない。その間に被災した信者 は離散してしまう。結果的に、修復、復旧、再建が困難となった宗 教施設もあることが東日本大震災に関して報告されている ${ }^{2)}$ 。一方 で、文化財未指定の宗教建築ではあるが、被災後に公的支援を受け ず、信者が自立的に復旧・修復をおこなった事例も存在する。熊本 市の中心部に所在するカトリック手取教会はその一例である。本稿 では、手取教会の被災後、誰がどのように自立的復旧をおこなった のか、それを可能ならしめた要因は何であるか、また被災前後には 誰がどのような営䌟をおこなってきたのかを調査し報告する。

関連する先行研究としては、地震等で被災した歴史的建造物の被 災状況報告はあるものの、宗教建築の自立的復旧の事例報告や研究 はほとんどみられない。1995 年の阪神淡路大震災で被災・焼失し たカトリック鷹取教会が、建築家の坂茂によって「紙の教会」とし て仮設的に再建された事例はよく知られている。これは坂の働きか けと建築専攻の学生たちの建設ボランティア、事業者からの建材寄 付、一般市民や企業の寄付金で実現したものである ${ }^{3)}$ 。鷹取教会が 所在する地域の震災被害があまりに甚大であったため、教会の司 祭・信徒は、地域の復旧が優先であり、教会堂の復旧・再建を優先 させるべきではないと考えた注1)。このため、ほとんどの信徒は「紙 の教会」の建設プロジェクトに直接は参加しなかった ${ }^{3)}$ 。しかし、 グラフィック・デザイナーである一人の信徒が、ボランティア・リー ダーとして活動し、事業実現において重要な役割を果たした ${ }^{3)}$ 。他 の信徒は建設ボランティアのために食事をつくった。宗教建築復旧
における信者と建築家の協働として有意義なプロジェクトである が、信者が担った役割は詳細には報告されていない。

2011 年には、ニュージーランドのクライストチャーチ・カテド ラル（英国国教会, 1904 年竣工）が地震で半壊した。カテドラルが 修復もしくは再建されるまでの仮設教会として、坂は Cardboard Cathedral（紙の大聖堂）を他の場所に建設した。このプロジェク トの報告によれば、カテドラルの司祭が発案し、坂に直接協力を求 めた ${ }^{4)}$ 。坂をはじめ多数の建設専門家と事業者の無償協力と多方面 からの寄付で実現した。信徒らは、半壊した歴史的建造物であるカ

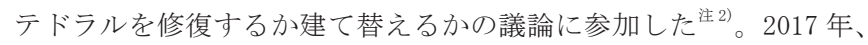
聖職者と信徒らは、カテドラルを全面的に建て替えるのではなく、 耐震補強や設備改修、部分的な建替えをしつつ、歴史的建造物とし て保存修復する決定をした。現在進行中の修復計画において信者は 積極的な関与を続けるものと思われる。事業が進行中ということも あり、詳細な報告や調査はなされていない。

筆者自身はこれまでに香港と日本におけるカトリック教会堂建 設・営繥の意味を社会、政治、宗教の文脈から解釈する研究をおこ なってきた ${ }^{5,6,7,8)}$ 。長期的に計画実施される建設や改修事業を研究 対象としており、災害復旧についてはこれまで报ってはこなかっ た。

社会学の領域では、叶堂隆三による研究があり、九州のカトリッ ク教会堂建設を可能とした主体や要素を分析している ${ }^{9)}$ 。自然災害 で被災した教会堂の再建についても言及があるが、個別の被災教会 堂において信徒が具体的にどのような自立的復旧・再建活動をおこ なったかという調查研究はされてはいない。

このように、国内外の被災宗教建築復旧における信者の自助とい う営為は、これまでほとんど注目されず、調査・報告されていない のである。

宗教建築は、建築の意匠や構造、歴史性が重要であるだけでなく、 そこでおこなわれる宗教活動によって信者たちを支え繋ぐ精神的価 
值があり、また、宗教組織がおこなう社会福祉活動や教育活動を通 して、信者と信者ではない人々を結ぶ社会的価值がある。災害によっ て宗教建築が失われれば、あるいは適切に復旧されなければ、信者 や地域住民に多大な喪失感を与え、信仰コミュニティ、地域コミュ ニティを破壊することにもなる。したがって、信者の自助によって 宗教建築が適切に復旧された事例を報告することには、歴史的建造 物保全の事例として意味があるだけでなく、建築が有する精神的・ 社会的価值の喪失を防ぐための示唆を得られる意義もある。また、 宗教建築の所有者・管理者である宗教組織とその信者が、宗教建築 の防災や苂害復旧計画をつくる際の重要な情報ともなる。

本研究は特に信者の「自助」に注目寸る。可能な限りの自助が早 期の復旧に有効であることは疑いない。他方で、災害緊急時には行 政の関与も求められる。行政が宗教建築復旧を支援する「公助」を 制度設計する際、宗教建築営繕の特徵や固有性を理解する一助に本 報告はなるだろう。

本調查の方法は、手取教会信徒及びカトリック福岡教区司祭への インタビュー、営繥と復旧に関する内部資料調查、営繥・復旧箇所 を実見する現地調査である。2017-18 年にかけて実施した。

\section{2. 震災前のカトリック手取教会の営繙}

カトリック手取教会は 1889 年、熊本市の借家にて設立された ${ }^{10)}$ 。 1928 年、現在の教会堂が竣工した (図 1)。設計・施工は鉄川与助 である。鉄筋コンクリート造、平面は三廊式、折上天井を持つ ${ }^{11}$ 。

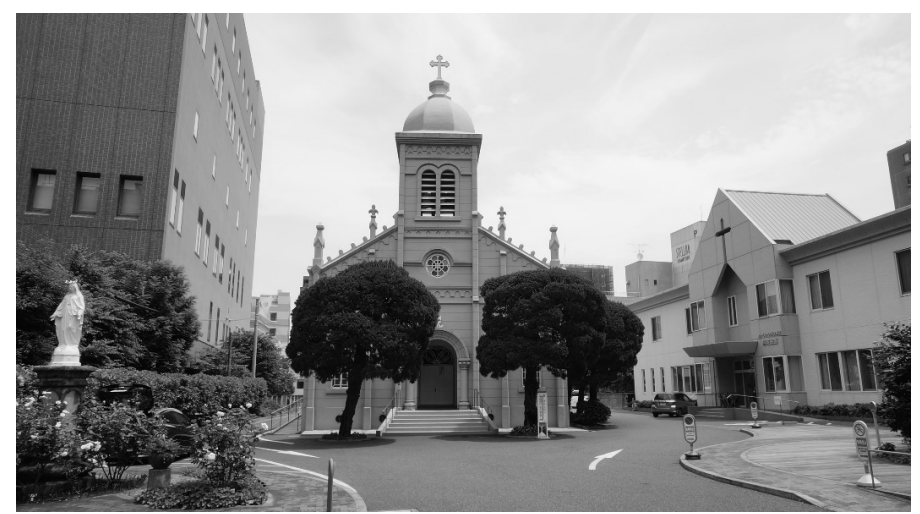

図 1 カトリック手取教会 (中央)、信徒会館·司祭館（右）、マリア像（左）

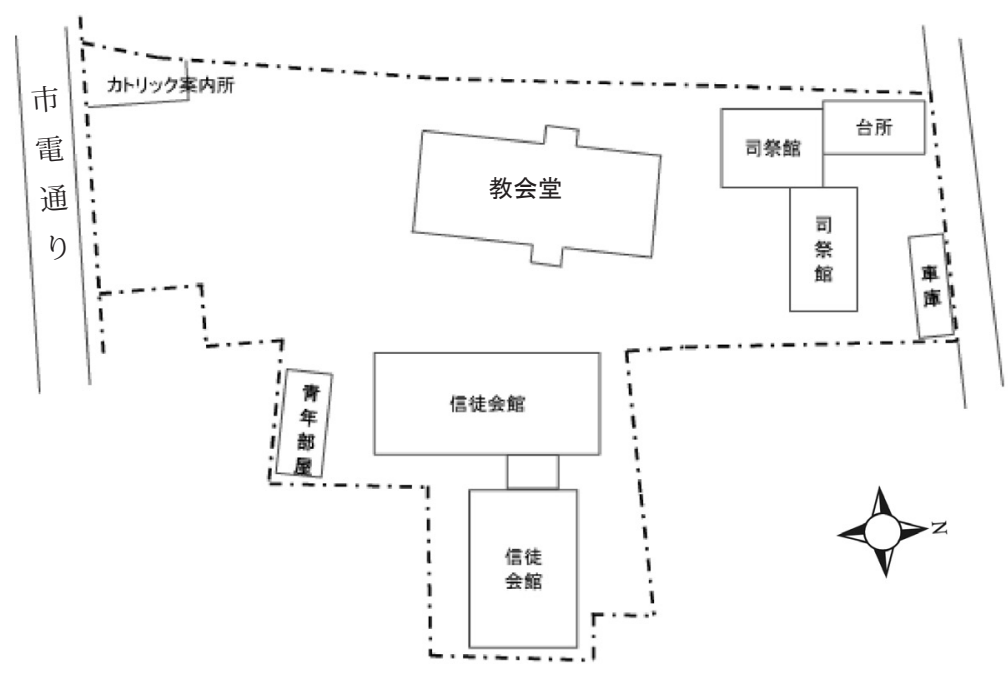

図 2 手取教会 敷地配置（2008 年建設事業前）城川康博提供
2018 年時点で国や地方自治体による文化財指定・登録はなく、今 後その予定もない。

2017 年時点での在籍信徒数は 996 名注 ${ }^{3)}$ 。この数には外国籍の信 徒は含まれていないが、ヴェトナム、フィリピン籍の信徒も 60 名 強いる。ミサ参加者は土日合計で平均約 400 名である。熊本市は、 長崎のように地域で広くカトリック信仰が継承されてきた土地柄で はなく、人口に占めるカトリック信者の割合は多くはない。手取教 会は都市部に所在するため、信徒には転勤者、熊本外出身者も少な くない。

手取教会では震災以前から信徒が自立的に営䌟をおこなってき た。このことが防災、減災、被災後の迅速な復旧に関係していると 考えられるため、被災前後の営繥体制についても調査した。

\section{1 信徒役員会営繥部長 2006 年以前}

2006 年以前は、手取教会信徒役員会のなかに営䌜担当の役員で ある「営繕部長」がいた注4)「信徒役員会」は、代表として選ばれ た信徒数名が、司祭とともに教会運営について審議する組織であ る。独立した営繕の委員会はなかった。

創立 100 周年を迎えた 1989 年以降、毎年 500 万円の教会堂建設 費を積み立てていた。

\section{2 建設委員会 2006-2016 年}

2000 年代前半、教会敷地内にある木造の司祭館（1924 年竣工、 1930 年増築）と信徒会館（1952 年竣工、1966 年増築）の老朽化が 進み、危険な状態であった（図 2） 注5,6)。2005 年に主任司祭として 着任した牧山勝美神父は耐震性を懸念した。教会堂の補修も必要で あった。

当時の信徒の年齢層は 50 歳代が約 $18 \%$ と最も多かった注 ${ }^{4,6)}$ 。信 徒は高齢化し、漸減していた。信徒数が減少すれば、営䋨をおこな う人も、教会一の献金額も減少してゆくことになる。このため役員 たちは、2005 年の時点で建設事業計画を始めないと、10 年後では 人材的にも資金的にも事業実現は難しくなると予測した。そこで、 信徒役員会において事業を計画し始めた。牧山主任司祭が「建設委 員会」の設立を信徒に提案した ${ }^{\text {5) }}$ 。これを受け、2006 年、建設委 員会を設立した。この委員会が建設事業の計画・管理を担うことと

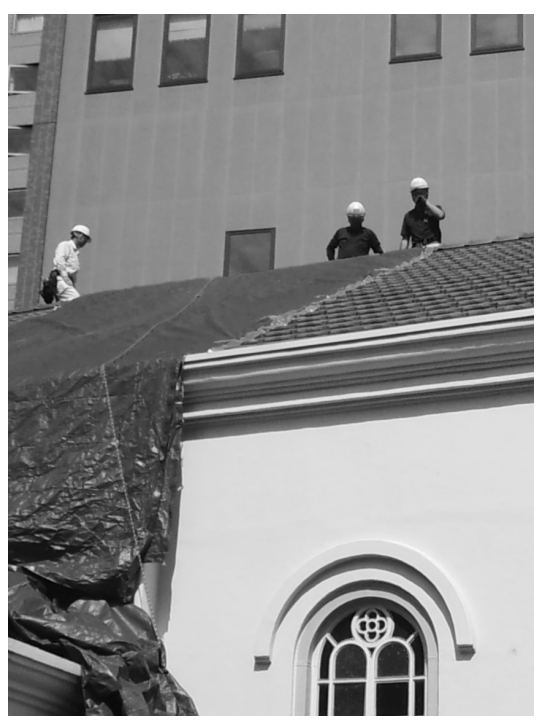

図 3 地震後、教会堂屋根にブルーシートを張る応急措置 城川康博提供 
した。

建設委員会委員長には信徒の城川康博が就任した。城川は熊本大 学病院で再開発事業を担当する部署に勤めており、建設事業管理に 精通していた注4)。当時は 50 歳代、信徒会長でもあった。

建設委員会のなかに 3 つのグループ（基本設計グループ、移転計 画グループ、資金管理グループ）を設置した。基本設計グループは、 事業の基本計画・基本設計を主導する。移転管理グループは、施工 前後に司祭館と信徒会館を移転する計画策定と実施を担当する。資 金管理グループは、事業資金となる献金納入確認をおこなう注6)。

委員長以外の建設委員は、主任司祭と信徒役員が推薦した注4) 推薦された信徒は皆引き受けた。委員は 50 歳代が中心であった。3 グループの委員構成は以下である。

基本設計グループは 7 名で、委員の職業は市役所職員（技術系）、 教員、自営業、公務員管理職経験者（城川）、主婦（教会婦人会会 長経験者)、医師 (教会婦人会会長経験者)、市役所職員（保健、信 徒会長経験者)。

移転管理グループは 5 名で、社会福祉士、定年退職者（営繥部長 経験者)、通信会社員、カテキスタ (伝道師)、建設資材販売事業者 (教会男性会会長経験者)。

資金管理グループは 8 名で、民間企業技術系社員、銀行員、保険 会社員、教会事務職員、大学事務職員 (教会維持費管理担当)、主婦 (教 会会計担当、2 名)、看護師。

上記の委員が選ばれた理由は以下である。建設関係や技術職の信 徒は、専門的・技術的な貢献が期待された。信徒会長、会計係、教 会内の各種グループ会長、営繕部長、教会職員を務めた経験のある 信徒は、教会の諸活動に必要な施設や設備、財政状況を熟知してい るため、計画設計にその経験を活用することが期待された。

2008 年の竣工まで、50 回以上委員会を開催した ${ }^{\text {4) }}$ 。

建設事業内容は、教会堂改修（外壁中性化防止、床補強、電気配 線・照明・空調改修、正面階段改修)、ブロック塀改修、信徒会館 と司祭館の建て替え、駐車場整備、案内所（宗教用品販売所）の移 転新築、マリア像の移転、植栽整備とした（図 1,2）注6,7)

教会堂を建て替えてはという意見もあったが、大多数の信徒は、 手取教会が鉄川与助の設計施工という歴史的・建築的価值を認識 し、また教会堂に愛着を持っていたこともあり、建て替えではなく、 改修することで合意した注6)。改修に際しては教会堂の外観保存を 重視した。

設計者の選定は、城川委員長が知人の紹介を得て幸設計を指名し

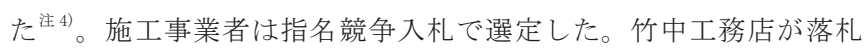
した。基本設計は、基本設計グループを中心とした建設委員と設計 者が協働した。設計コンセプトを以下のように決めた：「バリアフ リーを高めた、利便性・機能性の高い、信徒が集える空間の確保を しつつ、効率的な施設の利用を考え、必要最低限の部屋を設置」注7)。

教会堂東側（教会堂向かって右側）に信徒会館兼司祭館（1階信 徒会館、2 階司祭館)、北側（教会堂背部）に駐車場、市電通り沿 い西側にあった案内所を東側に移設新築、マリア像を移設すること とした（図 1,2)。城川委員長を中心に、既存諸施設の老朽化、案 内所一の入りにくさなどの問題を分析・提示し、基本設計案を全信 徒に説明し、同意を得た。

総事業費は、約 3 億 6 千万円と積算された。教区所有地であった
手取教会別館の土地を売却した額（1 億 3 千万円，総工費の $1 / 3$ に 相当）を工費にあてる許可を福岡教区司教から得た注7)。残額、寸 なわち総工費の $2 / 3$ （2 億 3 千万円）を手取教会の信徒が負担する こととなった。うち 8 千万円は、1989 年から積み立ててきた建設 積立金をあてることとした。残りの 1 億 5 千万円を、建設献金とし て信徒から新たに集めることになった。建設委員が、信徒の負担額 が一世帯 35 万円になると積算した。そのうえで、信徒が実際にい くら献金するかは、それぞれの事情があるため自己申告制とした。 献金方法は、一括、分割（年・半年・月払い）の様々な具体的方法

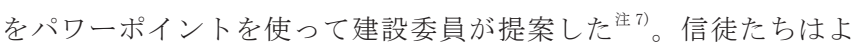
く理解し、反対はなかった。建設費は竣工後 7 年で完済した ${ }^{4 \text { 注。 }}$

2008 年の竣工後、基本設計グループと移転管理グループは解散 したが、一部の建設委員で、営繕のための新たな委員会設置の検討 をおこなった注4) 資金管理グループは集金活動のため、2015 年ま で活動を継続した。

\section{3. 熊本地震による被災と復旧}

2016 年 4 月の熊本地震により教会堂に被害が発生した。信徒会 館兼司祭館と案内所には被害はなかった。前震翌日に信徒会長の峯 和夫と信徒 1 名（民間企業技術系社員。教会男性会会長。後述する メンテナンス委員会委員となる）が教会堂床下に入り、柱の石造基 礎の被災有無を確認した注8)。両者は建設委員でもあったので、建 設事業を通して建物のことをよく知っていた。基礎の被災はなかっ

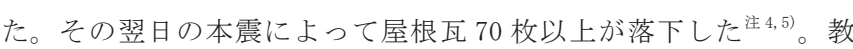
会堂内壁と天井漆喰、一部の柱と台座に亀裂が入った。教会堂内の ヨゼフ像が落下し破損した。十字架の道行きの聖画が半数以上 $(7$ 枚以上)落下し破損した。パイプオルガンのパイプが倒れ破損した。 敷地境界のブロック塀が一部損壊した。

峯信徒会長と建設委員が復旧対応にあたった。峯信徒会長が以下 の必要な復旧作業をとりまとめ、発注した注 4,5$)$ 。屋根瓦交換までの 応急措置として屋根にブルーシートを張る作業を竹中工務店に依頼 した（図 3）。竹中工務店に発注した理由は、2008 年事業の施工を 発注して以来、営繕の対応を依頼してきたためである。災害緊急時 なので、競争入札はおこなわなかった。同じく竹中に、教会堂の構 造点検、瓦の製造と莫き替え、柱と壁面の亀裂修復を発注した。瓦 は、台風にも耐えられるように、接着剤を注入するポリフォーム工 事とした。これらの工事は 2016 年 7 月に完了した。教会堂の被害 が重大なものではなく、復旧工事が迅速になされたため、教会堂が 使用できなかった期間は地震後 1-2 ヶ月ほどであり、長期に閉鎖さ れることはなかった。

他方、カトリック福岡教区は熊本地震発生後、ただちに対策本部 を設置し、「カトリック福岡教区熊本地震被災者支援室」を開設、「熊 本地震支援金」寄付を呼びかけ始めた注9)。支援金は 2017 年 3 月末 まで受け付けられ、総額 191, 523, 250 円が集まった ${ }^{10)}$ 。手取教会 をはじめ他の被災した教会堂やその他施設の復旧工事費には、この 支援金が使われた。

手取教会は、上述の教会堂屋根応急工事、屋根瓦ポリフォーム補 強工事、屋根瓦製造と莫き替え工事（足場工事含む）、柱亀裂補修 の合計 4, 374, 000 円に対する支援を教区に要請し、教区が支援金か ら支出した ${ }^{\text {注 } 10,11 \text { 。 }}$ 
以下の復旧工事は、手取教会の資金、すなわち手取教会信徒の献 金で負担した ${ }^{1 \text { i } 11}$ 。 十字架の道行きの聖画と額縁補修（聖画補修は 以前手取教会所属であった画家の信徒に発注。額縁補修は平野木工 所に発注)。パイプオルガンの破損したパイプ修理とパイプ固定(東 京の専門業者マナ・オルゲルバウに発注)。ヨゼフ像の新規購入、 落下防止のための固定作業 (京文堂に発注)。以上を峯信徒会長が とりまとめて発注した。損壊したブロック塀の修理を、当時信徒役 員会営繕部長であった信徒が自らおこなった。この信徒は前述の建 設委員会委員でもあり、後述するメンテナンス委員会の委員とな る。これらの作業は緊急性が比較的低いものでもあり、また時間の かかる作業でもあったので、教区支援金での負担を求めなかった。 地震後 1 年ほどで完了した。

\section{4. メンテナンス委員会 2017 年}

2017 年、手取教会は「教会建物維持管理委員会」（通称メンテナ ンス委員会) を設立した。先述の「建設委員会」を発展的に解消し、 移行させたものである注 ${ }^{2}$ 。メンテナンス委員会の役割は、建物維 持管理及び環境整備に関する事項について提言をまとめ、信徒役員 会に提案・報告することとした ${ }^{\text {注 }}$ 。

建設委員長であった城川がメンテナンス委員長に就任した。他の 委員は 8 名である。委員の職業は、建築士、医師、民間企業技術系 経験者（2018 年 5 月から信徒役員会営繥部長兼任）、民間企業管理 職経験者、公務員管理職経験者、市役所職員 (技術系)、定年退職 者 (2018 年 4 月まで信徒役員会営繥部長兼任)、主婦である ${ }^{\text {注4)。9 }}$ 名のうち 5 名は建設委員から移行した。4 名は新たに加入した。委 員の任期は設けていない。

メンテナンス委員会設立の目的は、信徒会館が䇋工して 10 年近 くが経過したので、今後改修などの必要性が出てくることを想定 し、それに対応寸るためでもあった。具体的には、信徒高齢化に伴 い葬儀が増加しているため、通夜の日に家族が信徒会館に宿泊でき るよう、ユニットバスの設置を計画している。また、教会堂正面階 段を高齢者が上がりやすいように改修する計画をしている。教会堂 や信徒会館の設備不具合の相談があった場合、メンテナンス委員会 が随時対応している。特に民間企業技術系社員であった信徒委員は 2017 年に定年退職してから、教会内の様々な営繕を中心的に担う ようになった。軽微な修理は自らおこなうなど、専門家ならではの 活踓をしている注 12)。2 2018 年 5 月からは信徒役員会営纁部長も務め ている。

\section{5. 手取教会における営繥の特徵}

手取教会の営縓と災害復旧には、以下の特徴があることが明らか になった。

\section{1 宣教師が育んだ信徒の主体性}

手取教会では営繕を含む教会運営において信徒が極めて主体的に 活動していることが明らかになった。信徒が建設事業計画までおこ なうことは、他の教会で一般的におこなわれているわけではない。 手取教会の信徒はなぜこのように主体的であるのかを信徒に尋ねた ところ、その理由のひとつはコロンバン会宣教師の方針によるとこ ろが大きいとのことであった注4)。その背景は以下である。1949 年、 中国大陸で共産党が政権をとり、宗教を弾圧し、外国人宣教師を国
外に追放するようになった。この宣教師たちの一部が来日、定住し、 日本の教会で宣教司牧をおこなうようになった。こうした背景にお いて、福岡教区熊本地区の教会は、1950 年にコロンバン会に司牧 が委託された ${ }^{\text {i⿱ } 13)}$ 。1960 年代前半にローマ・カトリック教会は第二 バチカン公会議を開催し、信徒と聖職者は信者として平等であるこ とを宣言し、信徒の積極的宣教活動や教会運営への参画を奖励し た。しかしながら、公会議後も長らく、日本を含む多くの地域では、 司祭があらゆることの主導者・意思決定者であり、信徒は司祭に従 属し続け、宣教や教会運営での主体性を発揮することは少なかった ${ }^{8)}$ 。そのような環境にありながらも、コロンバン会司祭は第二バチ カン公会議の精神をいち早く取り入れ、信徒の自主性、主体性を重 視する方針をとり、教会運営を信徒に任せてきた注 4,14$)$ 。また、コ ロンバン会司祭の提案で、手取教会では、男女が交代で信徒会長に 就任するようになった。従来は信徒会長は常に男性であったが、教 会には女性信徒のほうが多いのが実態でもあり、信徒がより平等に 教会運営を担って欲しいという意図が司祭にあったようである。こ れは手取教会の長所だと信徒は感じている注4)。こうした慣習のな かで、信徒も「自分でできることは自分でやる」という主体性を持 つようになった注4)

2005 年、手取教会の司牧はコロンバン会から福岡教区に移管さ れたものの、手取教会における信徒主体の伝統は、現在に至るまで 継承されている注4)。2008 年の建設事業、2016 年の災害復旧の際も、 信徒ができることは最大限おこなうという日ごろの意識が働いた。 この信徒の主体性が、迅速で自立的な復旧につながったといえる。

\section{2 専門家信徒の存在}

手取教会は、福岡教区のなかでは 8 番目に信徒数の多い教会であ る注3)。また都市部に所在することもあり、教会には建設関係の職 業に従事する信徒や、建設事業に携わったことのある信徒、技術職 の信徒が複数いた。本調查では、こうした信徒たちが営繥活動の中 心となっていることが明らかになった。信徒自身も手取教会には必 要な人材がそろっていると語った注4)

2008 年の大規模建設事業では、建設事業の経験が豊富な信徒が リーダーシップをとり、近代的なプロジェクト・マネジメントの方 式で効率的に事業を進めていった。外部の専門家に全面的に依存寸 るのではなく、信徒自身が自分の専門性を活用し事業計画を主導し たことにより、他の信徒への建設事業の説明、合意形成、資金調達 がスムーズに進んだと考えられる。教会に関わる建設事業で大きな 問題になるのが資金調達である。手取教会では 2008 年の事業に際 し、信徒各世帯がどれくらいの金額をどのくらいの期間負担すれば 事業が実現可能であるのかを、外部の専門家ではなく教会の仲間で ある建設委員の信徒が、具体的かつ現実的に提示したことにより、 比較的早い段階で資金調達の目途が立ち、資金が事業実施の大きな 障害になることはなかったと考えられる。

また、建設事業、災害復旧、その後の営繥において、建設専門家、 技術者の信徒がそれぞれの専門性に応じた役割分担をし、協力しな がら共に営繥をおこなっていることが本調查で明らかになった。

このように、建設専門家や技術者の信徒を中心としつつ、他の信 徒が協力するという体制の営繕をおこなってきたため、熊本地震の 際も、教会外の専門家に依存することなく、自立的に災害復旧をお こなうことができたといえる。 


\section{3 日常的な営縜体制}

信徒の多くが主体的であり、また、建設に精通している信徒がい たことにより、既に述べたように、被災前から教会堂と諸施設の 営繥を信徒が日常的におこなっていた。2006 年から「建設委員会」 を設置し、建設事業を実施した経験に加え、事業完了後も、信徒役 員会営繕部長や建設委員であった信徒が営繕をおこなっていたため に、被災後もただちに彼らが対応できた。平時から営繥体制が確立 されていたこと、それを通して信徒が建物を熟知していたことが、 迅速な復旧を可能にした。

\section{4 日常的営繥による防災・減災効果}

営繥担当の信徒たちは、歴史的建造物である教会堂のメンテナン スを定期的におこなっており、老朽化し耐震性に問題のある信徒会 館・司祭館の建て替えを 2008 年に済ませていた。その後も、信徒 たちが日常的に建物に気を配り、メンテナンスを続けていた。この 信徒による日常的かつ主体的、予防的な営繥が、結果として熊本地 震の際に深刻な被害を出すことなく、防災、減災につながったとい える。

\section{5 営繥の自立性}

信徒たちは、手取教会堂が歴史的建造物であることを認識し、大 切にしているが、教会堂の文化財指定や登録が必要とは考えておら ず、望んでいない注4)。信徒たちは教会堂を含めた諸施設の営繥を、 使用者である自分たち信徒が自立的におこなうことを大切にしてい る。信徒が自ら建設事業を計画・実施し、日常的に営緬をおこなう ことで、建物を熟知するようになり、災害などの緊急時にも迅速に 対応できるなど、営繕体制がうまく機能していることが本調査に よって分かった。また、自立的な営繕によって、信徒たちは教会堂 と諸施設への愛着、責任感をますます持つようになっていることが うかがえた。文化財指定がなされると、信徒の自立的な営繥、寸な わち、使用者である信徒たちが、諸施設をどのようにしていきたい かという意思決定をし、それを実行することが大きく制限されるた め、むしろ不都合になると考えている。

手取教会では文化財指定がないため、行政や外部専門家ではなく 信徒が営繕の意思決定者・実行者であり、自立的な営䌂を継続的に おこなってきたことが、災害時にも自立的な復旧を可能にしたとい える。

他方で、司祭館（1924 年築）と信徒会館（1952 年築、旧聖マリ ア学院を転用して信徒会館となった）が 2008 年に建て替えられる 際、これら建造物の増築や改修、転用の履歴調査・記録・評価がな されていれば、教会史や建築史、地域史にとって貴重な情報・資料 となったであろう。建て替えに際し、建築史学専門家の介入がなく、 記録調査がなされなかったのは、文化財指定・登録がなかったこと が一因でもあり、指定・登録がないために生じる損失が全くないと は言い切れない。

\section{6 喜びとしての営繥奉仕}

建設委員長・メンテナンス委員長の城川は、2008 年の建設事業 や被災後の復旧事業に膨大な時間と労力を費やした。教会奉仕をす るのは、自分の専門、能力を活か寸ことができ、喜びであるから苦 にならないと語った注 4 。

信徒会長の峯も、奉仕をする理由は楽しいからだと語った注4) 肉体的にはきついが、精神的には楽しいという。他の信徒のため、
神のためという共通した奉仕の目的を皆がもってやっているのだと 語った。このため、信徒の間や、司祭と信徒の間で、建設や復旧作 業をめぐって深刻な猙いが起きたことは一度もないという。

信徒が営繕奉仕を義務としてではなく、自身の専門性や能力を、 教会と仲間である他の信徒のために活かすことを喜びとし、楽しん でおこなっていることが、手取教会で効果的に営繥がおこなわれて いる理由のひとつでもあることが分かった。

\section{7 定年退職後の奉仕}

営繕や教会運営に奉仕している信徒の多くは定年退職者である。 彼らの多くは定年退職が近づいた 50 歳代もしくは退職後の 60 歳代 になって教会奉仕を始めた注4) 現役で仕事をしている時期はどの 信徒も仕事が忙しく、週 1 回ミ齐に参加するだけであり、教会奉仕 やその他の教会活動をする時間はなかったという。信徒自身も、現 役の時はそれぞれの仕事に没頭し、無理に教会奉仕をする必要はな く、定年退職後に時間ができた時に奉仕をしてくれればよいと考え ている注 ${ }^{4)}$ 。

建設、営繕、事業管理などの経験を社会で積んできた信徒が、主 に定年退職後に時間的余裕ができた時に、それぞれの経験を活用 し、教会営繕を支えていることが明らかになった。

\section{6. 結論}

カトリック手取教会における営繥と災害復旧に関して、本調査か ら以下のことが明らかになった。1950 年以降手取教会の司牧を担 当してきたコロンバン会司祭の方針で、信徒が主体的に教会運営、 営繕をおこなう習慣が確立した。2006 年から、信徒が主体となっ て大規模建設事業を計画し、「建設委員会」を設置した。そこには、 建設や関連する職業に従事している信徒が委員として参加した。多 くは、50 歳代もしくは定年退職者であった。それぞれの専門性と 豊富な経験を教会の建設事業に活用した。建設専門家以外に、教会 運営に詳しい信徒が参加し、計画設計に経験を反映させた。彼らの 奉仕によって事業を円滑に実施することができた。建設事業では、 耐震性に問題のある建物は建て替え、教会堂の劣化部分は補修し た。このため、2016 年の熊本地震での被害は最小限にとどまった。 信徒の主体的営繕活動が防災、減災につながったといえる。教会堂 には構造的な被害はなかったが、屋根瓦落下などの被害があり、こ れらの復旧には信徒会長、信徒役員会営繥部長、建設委員が迅速に 対応した。日常的に主体的営繕活動をおこなっていたことが、迅速 な対応を可能とした。また、歴史的建造物である教会堂が文化財指 定されていないことも、信徒の自立的営繕を可能としてきた要因で あり、結果的に迅速な災害復旧にもつながったといえる。復旧資金 については、緊急かつ大規模な工事には、カトリック福岡教区が広 く募った支援金が活用された。緊急性が比較的低く、小規模な復旧 工事は、手取教会の信徒が負担した。2017 年には建設委員会をメ ンテナンス委員会に移行させ、日常的営繥実施に加え、新たな事業 に取り組んでいる。そして、信徒たちは「信仰」、「神」という共通 の目的のもと、営繥という無償奉仕を喜びとしておこなっている。

手取教会は、宗教建築の自立的営繕・復旧の事例であり、他の宗 教建築営絟にとって示唆に富むものである。信徒自身の災害前から の継続的な自助が、結果的な防災、減災、迅速な復旧、歴史的建造 物の保全につながったことを示している。そしてその自助が、義務 
的で犠牲的な作業としてではなく、信仰に裏打ちされた自発的な奉 仕としてなされていることが、生きている宗教建築ならではの営䋨 のありようである。

現役で使用されている宗教建築の災害復旧や保存修復は、信者に よる自助が原則であり、手取教会ではそれが可能であった。しかし、 少なからぬカトリック教会が信者減少、財政難の課題を抱えてお り、営繥の自立は困難となっているという現実がある。また、建物 の被災の程度が甚大である場合など、明らかに自助だけでは復旧・ 保全が困難な場合も今後出てくるであろう。このような場合はやは り公助が有用であろう。公的支援制度設計に際しては、建築的価値 や社会的価值の保全という公益的側面を担保しつつも、信者たちの 自助、意思決定、信者が自分たちでできることをおこなうという宗 教的営為そのものを阻むことのない仕組みが求められることを、手 取教会の事例は示唆しているといえよう。

本研究に際し多大な御協力を頂いたカトリック手取教会主任司祭 櫻井尚明神父、峯和夫氏、城川康博氏、信徒各位、カトリック福岡 教区本部事務局長青木悟神父、土田充義鹿児島大学名誉教授に心か ら謝意を表します。本研究の一部は科学研究費基盤研究 (C)（課題 No.17K12614）の助成を受けて実施したものです。

\section{参考文献}

1）日本イコモス国内委員会 : 2016 年熊本地震 日本イコモス調査報告書 文化 財建造物の被害状況と復旧への展望, 2016.6

2) 文化庁文化部宗務課 : 東日本大震災における宗教法人の復興状況に関寸る 調査報告書, 2016.3

3) 坂茂 : 紙の建築 行動する, 筑摩書房,1998

4)Barrie, Andrew: Shigeru Ban: Cardboard Cathedral, Auckland University Press, 2014

5)Fukushima, Ayako: Catholic Laity Involvement in Church Building Project: Management of church building projects in the Hong Kong Catholic Diocese from the 1960 s to present, 日本建築学会計画系論文集 第 76 巻第 667 号, pp.1711-1719, 2011.9

6)Fukushima, Ayako and Yoshitake Doi: The Building Process and the Laity Involvement of Our Lady of Mount Carmel Church in Wanchai, Hong Kong: Church building system of the Catholic Diocese of Hong Kong, 日 本建築学会計画系論文集 第 78 巻 第 688 号, pp.1431-1440, 2013.6

7)Fukushima, Ayako and Yoshitake Doi: The Catholic Building Professional Advisory Group and Its Spirituality: Laity Involvement in Church Building System of the Catholic Diocese of Hong Kong, 日本建築学会計画系論 文集第 80 巻第 708 号, pp.429-439, 2015.2

8)Fukushima, Ayako: Laity Involvement in Catholic Church Buildings of Hong Kong: Interpretation within Religious, Social and Political Contexts from the 1950 s to 2015 , 学位請求論文 (九州大学) , 2016, http://catalog. lib.kyushu-u.ac.jp/en/recordID/1654990

9) 叶堂隆三：「山の教会」・「海の教会」の誕生, 九州大学出版会, 2018

10) 手取カトリック教会: 宣教百年の歩み 手取カトリック教会宣教百周年記 念誌, 手取カトリック教会, 1989

11）川上秀人：長崎県を中心とした教会堂建築の発展過程に関する研究, 学 位請求論文 (九州大学) , 1985

注

注 1）「信者」とは、司祭、修道者、信徒といった身分や立場の違いに関わ りなく全てのカトリック信者を指す。「信徒」は、司祭と修道者以外の信 者を指す。

注 2)Anglican Diocese of Christchurch: Cathedral Conversations, http:// cathedralconversations.co.nz/\#/, 2018 年 5 月 25 日 閲 覧; Cathedral
Working Group: About Reinstatement, https://www.ccwg.org.nz/aboutreinstatement/, 2018 年 10 月 15 日閲覧

注 3) カトリック福岡教区 : カトリック福岡教区報, 2018.5. 福岡教区には 55 の小教区があり、在籍の信徒総数は 29,075 人である (2017 年時点)。手 取教会は教区信徒総数の約 $3 \%$ を占める。

注 4) 筆者による手取教会信徒会長峯和夫及び教会建物維持管理委員会委員 長城川康博へのインタビュー, 2017 年 5 月 30 日, 2018 年 2 月 18 日, 手 取教会にて

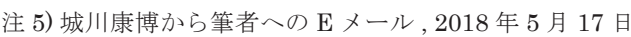

注 6) 建設委員会 : 手取教会の将来を見つめて!, 城川康博提供, 2006.3

注 7) 建設委員会 : 手取教会・聖堂改修等整備計画書, 城川康博提供, 2007.2

注 8) 筆者による峯和夫への電話インタビュー,2018 年 5 月 29 日

注 9) カトリック福岡教区 : カトリック福岡教区報,2016.4,2016.5。カトリッ ク福岡教区は、福岡県、佐賀県、熊本県を地理的な管轄範囲とする、ロー マ・カトリック教会の部分教会組織である。

注 10）カトリック福岡教区本部事務局長青木悟神父から筆者への資料提供, 2018 年 5 月 17 日, 2018 年 5 月 23 日。集まった支援金は、教会堂復旧工 事以外に、カトリック福岡教区所有の学校や社会福祉施設の復旧、被苂信 者への見舞金、カトリック福岡教区熊本地震被災者支援室運営経費にも使 用された。

注 11）筆者による城川康博への電話インタビュー, 2018 年 5 月 23 日；城川 康博から筆者への資料提供, 2018 年 5 月 28 日；筆者による峯和夫への電 話インタビュー,2018 年 5 月 31 日

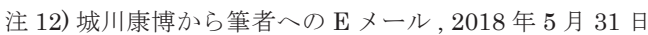

注 13) 新カトリック大事典編纂委員会 : 新カトリック大事典, 研究社, 1998 . 「聖コロンバン会（Missionary Society of Saint Columban）」は1916 年に アイルランドで設立された。1920 年に最初の宣教師が中国に派遣された。 日本への宣教師派遣は 1934 年に始まった。

注 14）新カトリック大事典編纂委員会: 新カトリック大事典, 研究 社 ,1998; Joseph Houston: Columban Missionaries in Hong Kong 19182018, Missionary Society of St. Columban, 2018, p77; Columban Lay Missionaryies: Who we are, https://www.columbanlaymissionariesireland. com/who-are-we, 2018 年 10 月 11 日閲覧. 1980 年代まで、コロンバン会 宣教師はアイルランド、イギリス、アメリカ合衆国、オーストラリア、ニュー ジーランド出身者であった。第二バチカン公会議の教えをコロンバン会宣 教師がいち早く取り入れた背景には、彼らが会を通じて最新の動向を入手 できたこと、彼らの母国語である英語での方が日本語よりも最新の情報を 早く、また豊富に入手できたこと以外に、宣教会設立後の早い時期から、 聖職者や修道者ではない信徒との協働を大切にし、積極的に推進してきた 経緯が関係していると推察される。1978 年、コロンバン会は "Columban Lay Missionary Program（聖コロンバン信徒宣教者プログラム）"を設立 し、信徒である宣教者を宣教地に派遣する事業を始めた。第一次派遣先は 日本とフィリピンであった。この活動はコロンバン会が信徒の主体性を重 視してきた重要な証左といえる。

[2018 年 6 月 1 日原稿受理 2018 年 10 月 3 日採用決定］ 